\title{
DAMPAK PANDEMI COVID-19 TERHADAP EKONOMI DAN LINGKUNGAN FISIK DI DESA WISATA DI BALI
}

\author{
Dewa Ayu Made Lily Dianasari \\ Program Studi Manajemen Kepariwisataan, Politeknik Pariwisata Bali \\ Jalan Darmawangsa, Kampial, Nusa Dua \\ lily.dianasari@gmail.com
}

\begin{tabular}{l|l|l} 
Received: August, 2021 & Accepted: August, 2021 & Published: September, 2021 \\
\hline
\end{tabular}

\begin{abstract}
The COVID-19 pandemic had a very significant impact on tourism in Bali. The decline of tourist visits had an impact on the economy and the physical environment in Bali, especially in Tourism Villages. The survey was conducted on the local communities involved in the management of tourist villages in Bali as many as 100 respondents to get the community's perception of the impact given to the economy and the physical environment during the COVID-19 pandemic. The sampling technique used was purposive sampling and quota sampling then analyzed by using confirmatory factor analysis. Community perceptions in tourist villages in Bali about the impact of the COVID-19 pandemic on the economy have a negative impact. This can be seen from the highest average value which has the highest loading factor matrix value of 0,773. The perception of communities in tourist villages in Bali about the impact of Covid-19 on the environment tends to have a positive impact. This can be seen from the results of the highest loading factor value in a positive statement with a value of 0,868; that is cleaner water conditions in the tourist village.
\end{abstract}

Keyword: impact, Covid-19 Pandemic, tourism village, economic and environment.

\begin{abstract}
Abstrak
Pandemi COVID-19 memberikan dampakyang sangat signifikan terhadap pariwisata di Bali. Penurunan kunjungan wisatawan berdampak terhadap perekonomian dan lingkungan fisik di Bali khususnya di desa wisata. Survei dilakukan kepada masyarakat lokal yang terlibat dalam pengelolaan desa wisata yang ada di Bali sebanyak 100 responden untuk mendapatkan gambaran persepsi masyarakat tentang dampak yang ditimbulkan terhadap ekonomi dan lingkungan fisik di masa pandemi COVID-19. Teknik pengambilan sampel yang digunakan adalah purposive sampling dan kuota sampling serta dianalisis dengan menggunakan confirmatory factor analysis. Persepsi masyarakat di desa wisata di Bali tentang dampak pandemi COVID-19 terhadap ekonomi memberikan dampak negatif. Hal ini dilihat dari nilai rata-rata tertinggi yang memiliki nilai matriks loading factor tertinggi 0,773. Persepsi masyarakat yang ada di desa wisata di Bali tentang dampak COVID-19 terhadap lingkungan cenderung memberikan dampak positif. Hal ini dapat dilihat dari hasil nilai loading faktor tertinggi pada pernyataan positif dengan nilai 0,868 yaitu semakin bersihnya kondisi air yang ada di desa wisata.
\end{abstract}

Kata Kunci: dampak, pandemi COVID-19, desa wisata, ekonomi dan lingkungan 


\section{PENDAHULUAN}

Pandemi COVID-19 (corona) saat ini mewabah hampir di seluruh negara di dunia. Wabah virus corona pertama kali terjadi di Wuhan China pada awal Desember 2019 dan menelan banyak korban jiwa. Virus Corona menyerang di Eropa, Amerika Serikat dan Asia Tenggara dan mulai menimbulkan kekacauan di Afrika dan Amerika Selatan (https://www.suara.com). Munculnya wabah COVID-19 tidak hanya menyebabkan kematian namun juga berdampak sangat besar terhadap seluruh industri yang ada di Indonesia salah satunya adalah pariwisata.

Pemerintah Indonesia tidak menerapkan sistem lockdown seperti yang dilakukan oleh beberapa negara besar dunia karena terkait dengan sistem stabilitas dan perekonomian masyarakat Indonesia. Di bidang pariwisata, pemerintah pusat dan daerah mengeluarkan kebijakan untuk menutup seluruh daya tarik wisata yang ada di Indonesia. Selain penutupan daya tarik wisata, sarana prasarana penunjang lainnya seperti airport, pusat perbelanjaan, hotel, dan restoran juga diberlakukan hal yang sama.

Adanya pemberlakuan lockdown di beberapa negara mengakibatkan menurunnya jumlah kunjungan wisatawan yang datang ke Indonesia dan Bali. Jumlah wisatawan yang berkunjung ke Bali dari tahun 2016-2019 mengalami peningkatan namun secara pertumbuhannya mengalami penurunan yang sangat signifikan. Dan yang paling signifikan yaitu pada Bulan JanuariMaret 2020 kunjungan wisatawan yang datang ke Bali mengalami penurunan cukup drastis seperti Tabel 1. Penurunan jumlah kunjungan wisatawan ini tentunya memberikan dampak yang positif dan negatif terhadap ekonomi dan lingkungan fisik.

Tabel 1: Tingkat Kunjungan Wisatawan ke Bali Tahun 2016-2020

[Sumber: Badan Pusat Statistik Provinsi Bali, 2020]

\begin{tabular}{lccccc}
\hline \multicolumn{1}{c}{ Bulan } & $\mathbf{2 0 1 6}$ & $\mathbf{2 0 1 7}$ & $\mathbf{2 0 1 8}$ & $\mathbf{2 0 1 9}$ & $\mathbf{2 0 2 0}$ \\
\hline Januari & 350.592 & 460.824 & 358.065 & 455.570 & 528.883 \\
Februari & 375.744 & 453.985 & 452.423 & 437.456 & 363.937 \\
M a r e t & 364.113 & 425.499 & 492.678 & 449.569 & 156.877 \\
A p r i l & 380.767 & 477.464 & 516.777 & 477.069 & 327 \\
M e i & 394.557 & 489.376 & 528.512 & 486.602 & 36 \\
J u n i & 405.835 & 504.141 & 544.550 & 549.516 & 604.323 \\
J u l i & 484.231 & 592.046 & 624.366 & 606.412 & \\
Agustus & 438.135 & 601.884 & 573.766 & 590.398 & \\
September & 445.716 & 550.520 & 555.903 & 567.967 & \\
Oktober & 432.215 & 465.085 & 517.889 & 497.925 & \\
November & 413.232 & 361.006 & 406.725 & 552.403 & \\
Desember & 442.800 & 315.909 & 498.819 & $\mathbf{6 . 2 7 5 . 2 1 0}$ & $\mathbf{1 . 0 5 0 . 0 6 0}$ \\
\hline Jumlah & $\mathbf{4 . 9 2 7 . 9 3 7}$ & $\mathbf{5 . 6 9 7 . 7 3 9}$ & $\mathbf{6 . 0 7 0 . 4 7 3}$ & $\mathbf{6 . 3 7}$ & \\
\hline Pertumbuhan & $\mathbf{2 3 , 1 4}$ & $\mathbf{1 5 , 6 2}$ & $\mathbf{6 , 5 4}$ & & \\
(\%) & & & &
\end{tabular}

Berdasarkan atas Tabel 2 dapat dijelaskan bahwa responden yang paling banyak adalah berjenis kelamin laki-laki (71\%), hal ini dikarenakan yang lebih banyak terlibat dalam pengelolaan desa wisata adalah laki-laki dibandingkan perempuan. Dengan tingkat umur 25 - 34 tahun sebanyak 34\%. Sedangkan 
berdasarkan atas tingkat pendidikan terbanyak adalah dengan tingkat Pendidikan sekolah menengah atas (SMA) yaitu $54 \%$, pekerjaan utama sebagai pegawai swasta (39\%) terutama di bidang pariwisata dan penghasilan yang terbesar adalah kurang dari dua juta rupiah sebanyak 54\%.

Deb dan Nafi (2020) menyatakan bahwa Bangladesh mengalami dampak buruk pada pariwisata inbound dan outbound. Wisatawan internasional dan domestik membatalkan pemesanan di Bangladesh, dan kegiatan wisata keluar juga telah dilarang. Maskapai penerbangan telah membatalkan penerbangan, hotel hampir sepenuhnya kosong, dan akibatnya agen pariwisata pendukung menghadapi kerugian ekonomi yang besar serta adanya pemutusan hubungan kerja di Bangladesh.

Pusat Penelitian Ekonomi LIPI pada akhir tahun 2019 lalu memprediksi pertumbuhan ekonomi nasional Indonesia sebesar 5,04\% untuk tahun 2020 ini. "Akibat wabah virus corona menyebabkan pelemahan perekonomian Tiongkok mengalami kontraksi" (http:/lipi.go.id).

Bobylev (2020) menyatakan bahwa krisis ekonomi yang terkait dengan COVID-19 akan memberikan pukulan kuat terhadap kesejahteraan finansial: penurunan produksi atau penutupan perusahaan dan organisasi di sektor publik dan swasta akan mengakibatkan penurunan pendapatan, peningkatan utang, masalah dengan hipotek, peningkatan pengangguran, dan lain-lain.

Menurut Verma dan Prakash (2020), pandemi COVID-19 telah berhasil memulihkan lingkungan sampai batas tertentu yang tentunya harus memberikan dampak positif pada perubahan iklim global. Tentu saja mengubah perilaku sehari-hari manusia dan sistem ekologi sekitarnya. Peneliti sumber daya lingkungan dari Standford University, Marshall Burke, melakukan beberapa perhitungan baik tentang penurunan polusi udara baru-baru ini di beberapa wilayah di China. Pengurangan polusi selama dua bulan. Hasilnya, mungkin saja pengurangan polusi ini telah menyelamatkan nyawa 4.000 anak di bawah 5 dan 73.000 orang dewasa di atas 70 di Cina (www.kompas.com).

Konsep desa wisata di Bali mendapat sambutan positif berbagai pihak dari masyarakat hingga pemerintah. Desa wisata adalah suatu wilayah pedesaan yang menawarkan keaslian baik dari segi sosial budaya, adat- istiadat, keseharian, arsitektur tradisional, struktur tata ruang desa yang disajikan dalam suatu suatu bentuk integrasi komponen pariwisata antara lain seperti atraksi, akomodasi dan fasilitas pendukung (Darsono, 2005). Desa wisata muncul sebagai wisata alternatif di mana terdiri dari suatu wilayah pedesaan yang memiliki potensi keunikan dan daya tarik wisata yang khas, baik berupa karakter fisik lingkungan alam pedesaan dan kehidupan sosial budaya masyarakat, yang dikelola dan dikemas secara menarik dan alami dengan pengembangan fasilitas pendukung wisatanya.

Adanya pandemi COVID-19 memberikan dampak terhadap desa wisata yang ada di Bali. Jumlah kunjungan wisatawan yang menurun ke Bali berpengaruh terhadap menurunnya kunjungan wisatawan ke desa wisata atau bahkan tidak ada sama sekali. Hal inilah yang menjadi latar belakang penulisan dampak COVID-19 terhadap ekonomi dan lingkungan fisik di desa wisata di Bali

\section{METODE PENELITIAN}

Pengumpulan data dengan menggunakan metode observasi, survei, dan wawancara. Survei dilaksanakan dengan menyebarkan kuesioner kepada masyarakat yang terlibat dalam pengelolaan desa wisata secara online dengan menggunakan google form.

Desa wisata yang menjadi sampel penelitian adalah 10 desa wisata yang ada di Bali yang diambil secara acak 
Dianasari

(random) karena keterbatasan waktu penelitian. Desa wisata yang dipilih adalah desa wisata yang sudah berkembang dan desa wisata mandiri. Jumlah responden dalam penelitian ini sebanyak 100 responden dengan teknik pengambilan sampel yang digunakan adalah quota sampling dimana pada masing-masing desa wisata ditentukan sebanyak 10 responden kemudian dipilih secara purposive sampling. Sampel sengaja dipilih oleh peneliti dari seorang informan berdasarkan kualitas yang dimiliki informan (Bernard, 2002; Lewis and Sheppard, 2006). Yang menjadi sampel yaitu masyarakat yang terlibat dalam pengelolaan desa wisata yaitu: ketua dan pengelola desa wisata, ketua pokdarwis, ketua pemuda, ketua PKK, dan pelaku wisata.

Teknik analisis data yang digunakan adalah teknik analisis data deskriptif kualitatif dan kuantitatif yaitu menggunakan confirmatory factor analysis. Uji validitas dan reliabilitas dilakukan terhadap 12 indikator yang terdapat dalam kuesioner. Seluruh indikator dinyatakan valid dengan nilai $\mathrm{R}$ hitung diatas 0,361, dan dinyatakan reliabel dengan nilai Crombach's Alpha 0,832 .

\section{HASIL DAN PEMBAHASAN \\ 3.1 Deskripsi Data}

Profil responden di Desa Wisata di Bali adalah sebagai berikut :

Tabel 2. Profil Responden

\begin{tabular}{|c|c|c|c|}
\hline No. & Karakteristik & Keterangan & $\begin{array}{c}\text { Persentase } \\
(\%)\end{array}$ \\
\hline \multirow[t]{2}{*}{1} & Jenis Kelamin & Laki-laki & 71 \\
\hline & & Perempuan & 29 \\
\hline \multirow[t]{5}{*}{2} & Umur & $<25$ tahun & 24 \\
\hline & & $25-34$ tahun & 34 \\
\hline & & $35-44$ tahun & 19 \\
\hline & & 45 - 55 tahun & 19 \\
\hline & & $>55$ tahun & 4 \\
\hline \multirow[t]{5}{*}{3} & Pendidikan & SMP & 2 \\
\hline & & SMA & 54 \\
\hline & & S1 & 21 \\
\hline & & S2 & 3 \\
\hline & & Lainnya & 20 \\
\hline \multirow[t]{7}{*}{4} & Pekerjaan Utama & Petani & 11 \\
\hline & & Pedagang & 6 \\
\hline & & PNS & 6 \\
\hline & & Pegawai Swasta & 39 \\
\hline & & Wiraswasta & 27 \\
\hline & & Ibu Rumah Tangga & 2 \\
\hline & & Lainnya & 9 \\
\hline \multirow[t]{4}{*}{5} & Penghasilan & $<2.000 .000$ & 54 \\
\hline & & $2.000 .000-3.000 .000$ & 23 \\
\hline & & $3.000 .000-4.000 .000$ & 18 \\
\hline & & $4.000 .000-5.000 .000$ & 5 \\
\hline
\end{tabular}

\subsection{Pembahasan}

Untuk mengetahui persepsi masyarakat lokal terhadap dampak ekonomi dan lingkungan fisik di masa pandemi COVID-19, peneliti menggunakan metode analisis data Confirmatory Faktor Analisis (CFA).

3.2.1 Uji KMO and Barlett's Test Variabel Dampak Ekonomi dan Lingkunga 
Tabel 3. Uji KMO and Barlett's Test Variabel Dampak Ekonomi dan Lingkungan

\begin{tabular}{lll}
\hline KMO and Bartlett's Test & \\
\hline \multicolumn{2}{l}{ Kaiser-Meyer-Olkin Measure of Sampling Adequacy } & 0,669 \\
\hline Bartlett's Test of & Approx Chi-Square & 347.936 \\
Sphericity & $d f$ & 66 \\
& Sig & 0,000 \\
\hline
\end{tabular}

Tabel 3 menjelaskan bahwa nilai Kaiser-Meyer-Olkin (KMO) dari 12 indikator dampak ekonomi dan lingkungan memiliki nilai 0,669 dimana hal ini berarti nilai KMO telah melampaui batas minimum yaitu 0,50. Nilai Bartlett's Test dari 12 indikator dampak ekonomi dan lingkungan berada pada nilai 0,000 hal ini juga menunjukan bahwa nilai Bartlett's Test sudah sesuai dengan ketentuan yaitu $\leq 0,05$. Dilihat dari uji KMO and Barlett's Test dari 12 indikator persepsi masyarakat lokal dampak COVID-19 terhadap ekonomi dan lingkungan menunjukkan bahwa indikator penyusun variabel dampak ekonomi dan lingkungan dikatakan memiliki korelasi dengan setiap indikator lainnya dan juga layak dilakukan kepada tahap selanjutnya.

\subsubsection{Uji Measure of Sampling Adequacy}

Terdapat 12 indikator yang mengukur persepsi masyarakat lokal dampak pandemi COVID-19 terhadap ekonomi dan lingkungan di desa wisata di Bali yang akan diujikan untuk menentukan hasil uji MSA. Berikut merupakan pemaparan dari hasil Uji Measure of Sampling Adequacy (MSA) Variabel Ekonomi dan Lingkungan dapat dilihat pada Tabel 4.

Tabek 4. Hasil Uji Measure of Sampling Adequacy

\begin{tabular}{clc}
\hline No & \multicolumn{1}{c}{\begin{tabular}{c}
\multicolumn{1}{c}{$\begin{array}{c}\text { Anti-image Matrices } \\
\text { Indikator }\end{array}$} \\
X1
\end{tabular}} & $\begin{array}{l}\text { Nilai } \\
\text { MSA }\end{array}$ \\
\hline X2 & $\begin{array}{l}\text { masyarakat di desa wisata. } \\
\text { Pandemi COVID-19 menyebabkan meningkatnya harga } \\
\text { kebutuhan pokok di desa wisata. }\end{array}$ &, $665^{\mathrm{a}}$ \\
X3 & $\begin{array}{l}\text { Pandemi COVID-19 meningkatkan kemampuan berusaha } \\
\text { masyarakat di desa wisata }\end{array}$ &, $717^{\mathrm{a}}$ \\
X4 & $\begin{array}{l}\text { Pandemi COVID-19 mengakibatkan menurunnya harga } \\
\text { jual tanah di desa wisata. }\end{array}$ &, $649^{\mathrm{a}}$ \\
X5 & $\begin{array}{l}\text { Pandemi COVID-19 mengakibatkan bertambahnya } \\
\text { jumlah pengangguran di desa wisata. }\end{array}$ &, $536^{\mathrm{a}}$ \\
X6 & $\begin{array}{l}\text { Pendemi COVID-19 menyebabkan meningkatnya } \\
\text { persaingan dalam mendapatkan lapangan pekerjaan. }\end{array}$ &, $616^{\mathrm{a}}$ \\
X7 & $\begin{array}{l}\text { Adanya pandemi COVID-19 mengakibatkan } \\
\text { berkurangnya kebisingan di desa wisata. }\end{array}$ &, $585^{\mathrm{a}}$ \\
X8 & $\begin{array}{l}\text { Pandemi COVID-19 mengakibatkan jumlah sampah di } \\
\text { desa wisata. }\end{array}$ &, $685^{\mathrm{a}}$ \\
X9 & $\begin{array}{l}\text { Pandemi COVID-19 mengakibatkan kondisi udara } \\
\text { semakin bersih di desa wisata. }\end{array}$ &, $699^{\mathrm{a}}$ \\
X10 & $\begin{array}{l}\text { Pandemi COVID-19 mengakibatkan kondisi air semakin } \\
\text { bersih di desa wisata. }\end{array}$ &, $696^{\mathrm{a}}$ \\
X11 & $\begin{array}{l}\text { Pandemi COVID-19 mengakibatkan bertambahnya } \\
\text { bangunan fisik di desa wisata }\end{array}$ &, $762^{\mathrm{a}}$ \\
X12 & $\begin{array}{l}\text { Pandemi COVID-19 mengakibatkan pencemaran di desa } \\
\text { wisata. }\end{array}$ &, $565^{\mathrm{a}}$ \\
\hline
\end{tabular}


Berdasarkan Tabel 4 dapat dilihat bahwa setiap indikator pada variabel dampak ekonomi dan lingkungan memiliki nilai MSA di atas nilai rata-rata yaitu $\geq 0,05$. Hal ini berarti setiap indikator pada variabel dampak ekonomi dan lingkungan dapat diprediksi dan juga dapat dianalisis lebih lanjut.

\subsubsection{Interpretasi persepsi masyarakat berdasarkan matriks}

\section{loading factor terhadap dampak Ekonomi dan Lingkungan}

Dengan adanya pandemi COVID-19 memberikan dampak secara global dan Bali khususnya yang sangat signifikan berpengaruh terhadap kondisi ekonomi masyarakat dan lingkungan sekitar. Berikut merupakan pemaparan dari hasil analisis data menggunakan analisis faktor konfirmatori berdasarkan dengan hasil nilai loading factor dari dampak ekonomi dan lingkungan pada Tabel 5.

Tabel Matrisks Loading Factor

\begin{tabular}{llc}
\hline No & \multicolumn{1}{c}{\begin{tabular}{c}
\multicolumn{1}{c}{$\begin{array}{c}\text { Anti-image Matrices } \\
\text { Indikator }\end{array}$} \\
X1
\end{tabular}} & $\begin{array}{l}\text { Aoading } \\
\text { Factor }\end{array}$ \\
X2 & $\begin{array}{l}\text { masyarakat di desa wisata. } \\
\text { Pandemi COVID-19 menyebabkan meningkatnya harga }\end{array}$ & 0,704 \\
kebutuhan pokok di desa wisata. & 0,662 \\
X3 & $\begin{array}{l}\text { Pandemi COVID-19 meningkatkan kemampuan } \\
\text { berusaha masyarakat di desa wisata }\end{array}$ & 0,557 \\
X4 & $\begin{array}{l}\text { Pandemi COVID-19 mengakibatkan menurunnya harga } \\
\text { jual tanah di desa wisata. }\end{array}$ & 0,525 \\
X5 & $\begin{array}{l}\text { Pandemi COVID-19 mengakibatkan bertambahnya } \\
\text { jumlah pengangguran di desa wisata. }\end{array}$ & 0,773 \\
X6 & $\begin{array}{l}\text { Pendemi COVID-19 menyebabkan meningkatnya } \\
\text { persaingan dalam mendapatkan lapangan pekerjaan. }\end{array}$ & 0,381 \\
X7 & $\begin{array}{l}\text { Adanya pandemi COVID-19 mengakibatkan } \\
\text { berkurangnya kebisingan di desa wisata. }\end{array}$ & 0,722 \\
X8 & $\begin{array}{l}\text { Pandemi COVID-19 mengakibatkan jumlah sampah di } \\
\text { desa wisata. }\end{array}$ & 0,839 \\
X9 & $\begin{array}{l}\text { Pandemi COVID-19 mengakibatkan kondisi udara } \\
\text { semakin bersih di desa wisata. }\end{array}$ & 0,547 \\
X10 & $\begin{array}{l}\text { Pandemi COVID-19 mengakibatkan kondisi air semakin } \\
\text { bersih di desa wisata. }\end{array}$ & 0,868 \\
X11 & $\begin{array}{l}\text { Pandemi COVID-19 mengakibatkan bertambahnya } \\
\text { bangunan fisik di desa wisata }\end{array}$ & 0,533 \\
X12 & $\begin{array}{l}\text { Pandemi COVID-19 mengakibatkan pencemaran di desa } \\
\text { wisata. }\end{array}$ & 0,806 \\
\hline
\end{tabular}

Pada Tabel 5 dapat dilihat bahwa hasil dari analisis faktor yang menentukan nilai loading factor di setiap indikator dari variabel dampak ekonomi dan lingkungan. Nilai loading factor akan menentukan korelasi antar item dari variabel dampak pariwisata. Menurut Hair et al. (1995) batas minimum untuk kelayakan nilai loading factor adalah $\geq$
0,30 dari semua indikator yang terdapat pada variabel dampak ekonomi semua nilai indikator memiliki nilai korelasi di atas 0,30 yang berarti semua indikator dikatakan mampu mencerminkan persepsi masyarakat lokal terhadap dampak ekonomi dan lingkungan dari pandemi COVID-19. 
Berdasarkan tabel di atas bahwa pandemi COVID-19 sangat berdampak negatif di bidang ekonomi yaitu meningkatkan jumlah pengangguran yang ada di Bali secara umum dan desa wisata khususnya. Hal ini dibuktikan dengan nilai loading factor yang paling tinggi yaitu 0,773. Dampak ekonomi terendah adalah pada indikator meningkatnya persaingan dalam mendapatkan pekerjaan dengan loading factor 0,381 . Hal ini juga sangat jelas terlihat bahwa di awal bulan Maret 2020 ketika mulai ditutupnya akses penerbangan ke Indonesia dan ke Bali mengakibatkan jumlah wisatawan yang berkunjung sedikit dan masyarakat yang bekerja di bidang industri pariwisata di rumahkan sehingga memang hampir tidak ada lapangan pekerjaan bagi masyarakat yang ada di desa wisata. Bahkan di saat pandemi COVID-19 ini masyarakat yang bekerja di industri pariwisata seperti hotel dan restoran kembali ke desa dengan mengikuti program padat karya dicetuskan oleh pemerintah daerah.

Dampak pandemi Covid-19 terhadap lingkungan memberikan dampak positif di mana kondisi air di desa wisata semakin bersih dan terjaga dengan nilai loading factor $(0,868)$. Walaupun demikian masih ada beberapa sampah di desa wisata yang kurang dikelola oleh masyarakat karena kurang sadarnya masyarakat membuang sampah sehingga menyebabkan pencemaran di desa wisata $(0,806)$. Dampak lingkungan terendah yang dipersepsikan masyarakat yang ada di desa wisata adalah pada indikator bertambahnya bangunan fisik di desa wisata dengan nilai loading factor 0,533 . Masyarakat beranggapan bahwa jangankan untuk membangun, sedangkan untuk biaya hidup saja susah saat ini yang disebabkan karena kehilangan pekerjaan.

\section{KESIMPULAN}

Berdasarkan pemaparan atas pembahasan di atas dan hasil analisis data terkait dengan dampak pandemi
COVID-19 terhadap ekonomi dan lingkungan dari sisi persepsi masyarakat, maka dapat disimpulkan sebagai berikut:

1) Persepsi masyarakat yang ada di desa wisata di Bali tentang dampak pandemi Covid-19 terhadap ekonomi memberikan dampak negatif. Hal ini dilihat dari nilai rata-rata tertinggi dari dampak ekonomi memiliki nilai matriks loading factor tertinggi 0,773. Hal ini sangat jelas terlihat bahwa banyaknya jumlah pengangguran di Bali dan di desa wisata pada khususnya di masa pandemi COVID19.

2) Persepsi masyarakat yang ada di desa wisata di Bali tentang dampak Covid19 terhadap lingkungan cenderung memberikan dampak yang positif. Hal ini dapat dilihat dari hasil nilai loading factor tertinggi pada pernyataan positif dengan nilai 0,868 yaitu semakin bersihnya kondisi air yang ada di desa wisata.

\section{PERNYATAAN PENGHARGAAN}

Terima kasih penulis ucapkan kepada Politeknik Pariwisata Bali yang telah memberikan kesempatan untuk melaksanakan penelitian serta mendanai seluruh kegiatan penelitian. Penulis ucapkan terima kasih pula kepada seluruh pengelola desa wisata yang ada di Bali yang telah meluangkan waktunya sebagai informan sehingga penelitian dapat terselesaikan tepat waktu. Teruntuk tim Penelitian dan Pengabdian kepada Masyarakat Politeknik Pariwisata Bali yang telah mendukung dari pengajuan proposal sampai menjadi sebuah laporan penelitian, serta tim reviewer yang meluangkan waktunya memberikan masukan terkait penulisan artikel dalan jurnal ini.

\section{DAFTAR PUSTAKA}

Bernard, H.R. (2006). Research Methods in Anthropology: Qualitative and quantitative methods. 3rd edition. AltaMira Press ,Walnut Creek, California. 
http://ndl.ethernet.edu.et/bitstrea m/123456789/40820/1/17.pdf.pdf Bobylev, Sergey N. (2020). "Environmental consequences of Covid-19 on the Global and Russian economic". Journal Population and Economics. Vol 4. Number 2. DOI 10.3897/popecon.4.e53279

Darsono. (2005). Pengertian Desa. dari: http://desasentonorejo.wordpress.c om/bab-ii/

Deb, Santus Kumar dan Nafi, Sholeh Md. (2020). "Impact of COVID-19 Pandemic on Tourism: Perceptions from Bangladesh". https://www.researchgate.net/publ ication/342472798_Impact_of_COVI D19_Pandemic_on_Tourism_Perceptio ns_from_Bangladesh

Lewis, J.L. \& S.R.J. Sheppard. (2006). Culture and communication: can landscape visualization improve forest management consultation with indigenous communities? Landscape and Urban Planning 77:291-313.

https://doi.org/10.1016/j.landurbpl an.2005.04.004

LIPI. (2020). Dampak Virus Corona pada Laju Ekonomi Indonesia 2020. Retrieved from: http://lipi.go.id/siaranpress/Dampa k-Virus-Corona-pada-Laju-EkonomiIndonesia-2020/21963

Sumatiningtyas, H.K.N. (2020). "Dampak Pandemi Virus Corona pada Lingkungan, Polusi Udara Global Turun" Kompas.com. Retrieved from:

https://www.kompas.com/sains/re $\mathrm{ad} / 2020 / 03 / 17 / 190300123 /$ damp ak-pandemi-virus-corona-padalingkungan-polusi-udara-globalturun?page $=$ all

Verma, A.K. \& Prakash, S. (2020). "Impact of Covid-19 on Environment and Society". Journal of Global Biosciences. Volume 9. Number 5. https://www.researchgate.net/publ ication/342625420_IMPACT_OF_CO VID-

\section{9_ON_ENVIRONMENT_AND_SOCIE} TY 